\title{
Comparative study of unmodified Iyi-Nsukka and unmodified Ukpo kaolinite clays as catalysts for transesterification of gmelina seed oil
}

\author{
${ }^{1}$ Odenigbo J.O., ${ }^{2}$ Chime T.O., ${ }^{2}$ Egbuna S.O. \\ ${ }^{1}$ Engineering Research Development Production Department, Projects Development Institute (PRODA) Enugu, \\ P.M.B.01609 Enugu, Nigeria.
}

${ }^{2}$ Department of Chemical Engineering, Enugu State University of Science and Technology, P.M.B 01660, Enugu state, Nigeria.

Correspondence: +2348038993501; Email: judeodenigbo2@gmail.com.

DOI: 10.29322/IJSRP.11.08.2021.p11672

http://dx.doi.org/10.29322/IJSRP.11.08.2021.p11672

\begin{abstract}
The comparative study of unmodified indigenous kaolin clays as catalysts for biodiesel production were investigated. The unmodified lyi-Nsukka kaolinite clay and unmodified Ukpo Kaolinite clay catalysts were prepared, characterised by X-ray diffraction (XRD), Fourier transform infrared spectroscopy (FTIR), Scanning electron microscopy (SEM) and Atomic abrasion spectrophotometry (AAS) to verify catalyst properties. Gmelina seed oil was extracted using Soxhlet extraction method using hexane as solvent. The percentage oil extracted from gmelina seed oil was 50\%, proven its viability as feedstock for biodiesel production. The extracted lipid was characterised to determine the fatty acid profile using Gas chromatography/ mass spectroscopy (GC/MS) Shimadzu, Japan. The methyl ester produced by transesterification of gmelina seed oil were within acceptable limits of ASTM standard. Design of experiment was done using Central Composite Design (CCD) which was adequate in predicting and optimizing the biodiesel production, the optimal process parameters include: reaction time 3 hours, catalyst concentration $3 \mathrm{wt}$. percent, methanol/oil ratio $12: 1$, reaction temperature $60^{\circ} \mathrm{C}$ and agitation speed 300rpm. It were observed that surface area $\left(721 \mathrm{~m}^{2} \mathrm{~g}_{-}{ }^{1}\right.$ and $\left.778 \mathrm{~m}^{2} \mathrm{~g}-{ }^{-1}\right)$ and porosity $(51.36 \%$ and $52.75 \%)$ of the clay catalysts affect biodiesel yield of $84.5 \%$ and $86.4 \%$ respectively, for unmodified Iyi-Nsukka kaolinite clay catalyst (UMIKCCat) and unmodified Ukpo Kaolinite catalyst (UMUKCCat).
\end{abstract}

Index term-Unmodified Iyi-Nsukka kaolinite clay catalyst, Unmodified Ukpo Kaolinite clay catalyst, transesterification, gmelina seed oil.

\section{Introduction}

Kaolinite is the major mineral component of kaolin, It usually contain quartz and mica, It may also contain feldspar, illite, montmorillonite, ilmenite, anastase, haematite, bauxite, zircon, rutile, kyanite, silliminate, graphite, attapulgite and halloysite in minor proportions (Adam,1975;Varga,2007). Chemically kaolin is known as 1:1 layer sheet structured hydrated aluminium silicate of very fine particle size with one silicon-oxygen $\left(\mathrm{SiO}_{4}\right)$ tetrahedral layer and one alumina $\left[\mathrm{Al} \quad(\mathrm{O}, \mathrm{OH})_{6}\right]$ octahedral layer sheet $\left[\mathrm{Si}_{2} \mathrm{O}_{5}\right]_{2}$ with pseudo-hexagonal symmetry, bonded together having apical oxygen and exists alternately. Its theoretical formula is $\mathrm{Si}_{2} \mathrm{Al}_{2} \mathrm{O}_{5}(\mathrm{OH})_{4}$ and can equally be represented as $\mathrm{Al}_{2} \mathrm{O}_{3} \cdot 2 \mathrm{SiO}_{2} \cdot 2 \mathrm{H}_{2} \mathrm{O}$ and $\mathrm{Al}_{2} \mathrm{O}_{7} \mathrm{Si}_{2} \cdot 2 \mathrm{H}_{2} \mathrm{O}$, having molecular weight of 258.07gmol- ${ }^{-1}$ (Ledoux, 1966; Madejova, 2003; Okada, 1998 and Varga, 2007)

Kaolin is one of the clay mineral widely used for a large number of applications, such as in ceramics, paper coating, paper filling, paint extender, rubber filler, plastic filler, cracking catalysts or cements its potentials in transesterification catalyst is still being investigated. Despite the actual dominant use of microporous zeolite acid catalysts in modern petrochemical processes, there is still a wide interest in the use of clays, not only because of their low cost but also because the structure and dimension of their pores appear more suitable, compared to zeolites, for the cracking of larger molecules (Lenarda, 2007). The industrial utilization of kaolinite is closely related to its reactivity and surface properties, which depend strongly on surface modification. Several methods have been suggested in literature to improve the 
properties of clay materials which include among others mechano-chemical activation (Ledoux,1966; Mako,2006; Temuujin,2001; Wada, 1962, Vagvlgyi,2008; Temuujin et al., 2001) intercalation (Horvath, 2005; Wada, 1962) thermochemical treatment (Belver, 2002; Varga, 2007) and chemical activation (Rhodes, 1991; Rodrigues, 2003, Varga, 2007) whereas the study seek to evaluate catalytic activities of our indigenous clays in its unmodified form as heterogeneous catalysts for transesterification of gmelina seed oil.

In trans-esterification reaction, catalysts are used to improve the yield of Biodiesel production, these catalysts can be classified, according to their chemical presence in the reaction, as homogeneous or heterogeneous catalysts. Homogeneous catalysts act in the same liquid phase as the reaction mixture. Industrial scale biodiesel production is usually performed with homogeneous alkaline catalysis. This process provides very high yields, although the purification steps are costly (Singh, 2010; Stavarache, 2005). Whereas heterogeneous catalysts act in a different phase from the reaction mixture, usually as a solid (Demirbas, 2003) the possibility of catalyst recovery and recyclability, minimized corrosion capacity, ease of handling and separation from the reaction medium (Horvath, 2003; Talebian-Kiakalaieh, 2013; Xu, 2008; Zhou, 2010). For these reasons, they are often called "environmentally friendly" (Demirbas, 2009; Singh, 2010).

It is very important to find cheap raw materials without competition with arable land and food for the development of biofuel, such as nonedible oil and fats. Gmelina seed oil is a very promising source for biodiesel. Gmelina is a big forest tree popular for its wood used for making furniture and as building materials. Gmelina is a fast growing tree, which grows on different localities and prefers moist fertile valleys with $750-5000 \mathrm{~mm}$ rainfall. The gmelina tree attains moderate to large height up to $40 \mathrm{~m}$ and $140 \mathrm{~cm}$ in diameter (Adam, 1975). It is occurring naturally throughout greater part of India at altitudes up to $1500 \mathrm{~m}$. It also occurs naturally in Myanmar, Thailand, Laos, Cambodia, Vietnam, and in southern provinces of China, and has been planted extensively in Sierra Leone, Nigeria and Malaysia (Burkill, 2000). This tree is commonly planted as a garden and an avenue tree; growing in villages along agricultural land and on village community lands and wastelands. Flowering takes place during February to April whereas fruiting starts from May onwards up to June. The fruit is up to $2.5 \mathrm{~cm}$ long, smooth, dark green, turning yellow when ripe and shas a fruity smell.
The aim of this study is to evaluate the performance of unmodified Iyi-Nsukka kaolinite clay and unmodified Ukpo Kaolinite clay as catalyst for transesterification of gmelina seed oil in there raw (unmodified) form prior to modifications.

\section{Experimental}

Iyi-Nsukka kaolinite clay was sourced from Iyi-Nsukka basin in Nsukka, Enugu state, Nigeria while Ukpo kaolinite clay was sourced from Ukpo, Anambra state, South-eastern, Nigeria. Gmenila seeds were sourced from Enugu state forest reserve in Enugu.

Clay catalysts preparation- Unmodified Iyi-Nsukka kaolin clay catalyst (UMIKCCat) and unmodified Ukpo kaolin clay catalyst (UMUKCCat) were prepared according to (Xu, 2008; Lenarda, 2007). Collected clay samples were dried using laboratory hot air oven at $110^{\circ} \mathrm{C}$ for 4 hours to remove moisture. The samples were pulverized using ball mill and sieved using mechanical sieve machine (manufactured by CISA) England with sieve size $250 \mu \mathrm{m}$.

Catalysts Characterisation- X-ray Diffraction (XRD) of unmodified Iyi-Nsukka kaolinite clay catalyst and unmodified Ukpo kaolin clay catalyst samples were determined using an EMPYREAN Diffractometer manufactured by PA analytical, operating at generator voltage: $45 \mathrm{kv}$, tube current: $40 \mathrm{~mA}$ and measurement temperature: $25^{\circ} \mathrm{C}$. The Fourier transform Infrared spectra (FTIR) of the kaolinite clay catalysts samples were done by the use of the FTIR spectrophotometer using transmittance method with range 4000 - 650 wavenumber $\left(\mathrm{cm}^{-1}\right)$. To show the functional group present in these catalysts samples. Scanning electron microscope (SEM) analysis of the kaolinite clay catalysts samples were done using Scanning electron microscope (SEM) model: Phenom ProX, manufactured by Eindhoven, Netherland to show the morphology of the catalysts. Atomic absorption spectrophotometry (AAS) of unmodified IyiNsukka kaolinite clay catalyst and unmodified Ukpo kaolin clay catalyst samples were determined using Atomic absorption spectrophotometer 210VGP, manufactured by Buck Scientific, England. Gmelina seed oil extraction was done by soxhlet extraction method using n-hexane as solvent.

The percentage oil yield was calculated using equation: $\mathrm{Y}=\left[\left(\mathrm{w}_{2} / \mathrm{w}_{1}\right) * 100\right]$

$$
\begin{aligned}
\text { Where } \mathrm{Y} & =\text { Volume of oil }(\%) \\
\mathrm{w}_{2} & =\text { weight of oil extracted } \\
\mathrm{w}_{1} & =\text { weight of seed samples }
\end{aligned}
$$


Gmelina seed oil characterisation was carried out using GC-MS (Shimadzu, Japan, Model: GCMSQP2010 PLUS).

A fractional factorial design was used to obtain quadratic model, consisting of factorial trials to estimate quadratic effects. To examine the combined effect of the five different factors (independent variables); catalyst concentration, methanol/oil molar ratio, reaction temperature, reaction time and agitation speed, on biodiesel yield and derive the model, a two-level- five-factor $\left(2^{5-1}\right.$ $+2 * 5+6)$ Central Composite Response Design $=32$ experiments were performed. The matrix for the five variables was varied at two levels $(-1$ and +1$)$. The lower level of variable was designated as "-1" and higher level as " +1 ". The experiments were performed in random order to avoid systematic error. Design Expert 11.0. was used. The response was expressed as \% yield of biodiesel.

Biodiesel yield was given as; $\mathrm{Y}=\left[\left(\mathrm{V}_{2} / \mathrm{V}_{1}\right) * 100\right]$

$\mathrm{V}_{2}=$ volume of biodiesel produced .

$\mathrm{V}_{1}=$ initial volume of oil.

\subsection{Results and Discussion}

The X-ray diffraction (XRD) of unmodified Iyi-Nsukka kaolinite clay catalyst and unmodified Ukpo kaolin clay catalyst samples were presented in Figure 1 and Figure 2, respectively. The visible compounds present in unmodified IyiNsukka kaolin clay catalyst include: Quartz and kaolinite representing $56 \%$ and $44 \%$ with displacements: 0.000 and $0.000[\AA]$ at $\left[{ }^{\circ} 2 \mathrm{Th}\right]$ and chemical formulas: $\mathrm{Al}_{2} \mathrm{Si}_{2} \cdot \mathrm{O}_{9}$ and $\mathrm{Si}_{3} . \mathrm{O}_{6}$. While visible compounds present in unmodified Ukpo kaolin clay catalyst include: Quartz $51.69 \%$, Kaolinite $42.3 \%$ and phengite $4.2 \%$, with displacements: $0.05 ; 0.080$ and $0.091[\AA]$ at [ $\left.{ }^{\circ} 2 \mathrm{Th}\right]$ with chemical formulas: $\mathrm{Al}_{2} \mathrm{Si}_{2} . \mathrm{O}_{9} ; \mathrm{Si}_{6} . \mathrm{O}_{6}$. and $\mathrm{K} 1.90 \mathrm{Na0} .10 \mathrm{Al}_{9}$ respectively .

The Fourier transform infrared spectra (FTIR) of unmodified Iyi-Nsukka clay catalyst and unmodified Ukpo kaolin clay catalyst were shown in the Figure 3 and Figure 4, respectively. The band regions $3690.1 \mathrm{~cm}^{-1}$ and $3623.0 \mathrm{~cm}^{-1}$ were assigned to Al- - - O- H stretching, while region $1636.3 \mathrm{~cm}^{-1}$ was ascribed to $\mathrm{H}-\mathrm{O}-\mathrm{H}$ bending possibly absorbed water. The region $1114.5 \mathrm{~cm}^{-1}$ indicates the presence of Si-O stretching, the region 782.7 and $749.2 \mathrm{~cm}^{-1}$ were ascribed to $\mathrm{OH}$ deformation linked to $\mathrm{Al}^{3-}$ whereas the band region $678.4 \mathrm{~cm}^{-1}$ shows the presence of $\mathrm{Si}$ - quartz. The band region $909.5 \mathrm{~cm}^{-1}$ was ascribed to $\mathrm{OH}$ deformation, the region $998.9 \mathrm{~cm}^{-1}$ represents $\mathrm{Si}-\mathrm{O}$ quartz. , In unmodified Ukpo kaolin clay catalyst, the bands at $3693.8 \mathrm{~cm}^{-1}$ and $3652.8 \mathrm{~cm}^{-1}$ were ascribed to $\mathrm{Al} \mathrm{-} \mathrm{-} \mathrm{O-H,}$ stretching, the region $797.7 \mathrm{~cm}^{-1}$ was assigned to $\mathrm{OH}$ deformation linked to $\mathrm{Al}^{3-}$, the band region $1002.7 \mathrm{~cm}^{-1}$ represents $\mathrm{Si}-\mathrm{O}$ stretching, the band region $1028.7 \mathrm{~cm}^{-1}$ was ascribed to $\mathrm{Si}-\mathrm{O}$ stretching, clay minerals. The region $682.1 \mathrm{~cm}^{-1}$ was assigned to Si-O quartz, the band region $909.5 \mathrm{~cm}^{-1}$ indicates $\mathrm{OH}$ deformation linked to $\mathrm{Al}^{3-}$, the region $1118.2 \mathrm{~cm}^{-}$ ${ }^{1}$ was assigned to $\mathrm{Si}-\mathrm{O}$ stretching, the band region $752.9 \mathrm{~cm}^{-1}$ was ascribed to $\mathrm{Si}-\mathrm{O}$ quartz. This observation is in line with the findings of Diko, et al (2016), Maryam et al., (2014), Panda et al. (2010), Oueda et al.,(2017)and Park et al., (2007).The Scanning electron microscopy (SEM) of unmodified Iyi-Nsukka kaolin clay catalyst and unmodified Ukpo kaolin clay catalyst were shown in Plate 1 and Plate 2, respectively. The scanning electron microscopy (SEM) of unmodified Iyi-Nsukka kaolin clay catalyst revealed the presence of large particles that looks like several flaky particles stacked together as agglomerates. It has inter-particle relation which shows interlocking of kaolinite particles with aggregate arrangement. Also the scanning electron microscopy (SEM) of unmodified Ukpo kaolin clay catalyst revealed the presence of agglomeration of particles of kaolinite with aggregate arrangement. The results was similar to the findings of Panda et al. (2010), Oueda et al. (2017) and Park et al. (2007). Table 1, show the elemental composition of unmodified Iyi-Nsukka kaolinite clay catalysts (UMIKCCat) and unmodified Ukpo kaolin clay catalyst (UMUKCCat), the results show that $\mathrm{Al}_{2} \mathrm{O}_{3}$ and $\mathrm{SiO}_{2}$ were the major constituent of both clays. Table 2, show the Physicochemical properties of unmodified Ukpo kaolin clay catalyst and unmodified Iyi-Nsukka clay catalyst, it shows that all properties were within the range for kaolin clay whereas Table 3 shows the physicochemical properties of gmelina seed oil, it was observed that all parameters were within the range for biodiesel production. The fatty acid composition of gmelina seed oil was shown in Figure 5, Stearic acid methyl ester is the dominant methyl ester (40.08\%), Octadecanoic acid methyl ester $(36.64 \%)$ Oleic acid $(6.31 \%)$, Pentadecanoic acid methyl ester $(5.18 \%)$, Archidic acid methyl ester (1.49\%) and Palmitic acid $(0.77 \%)$. 


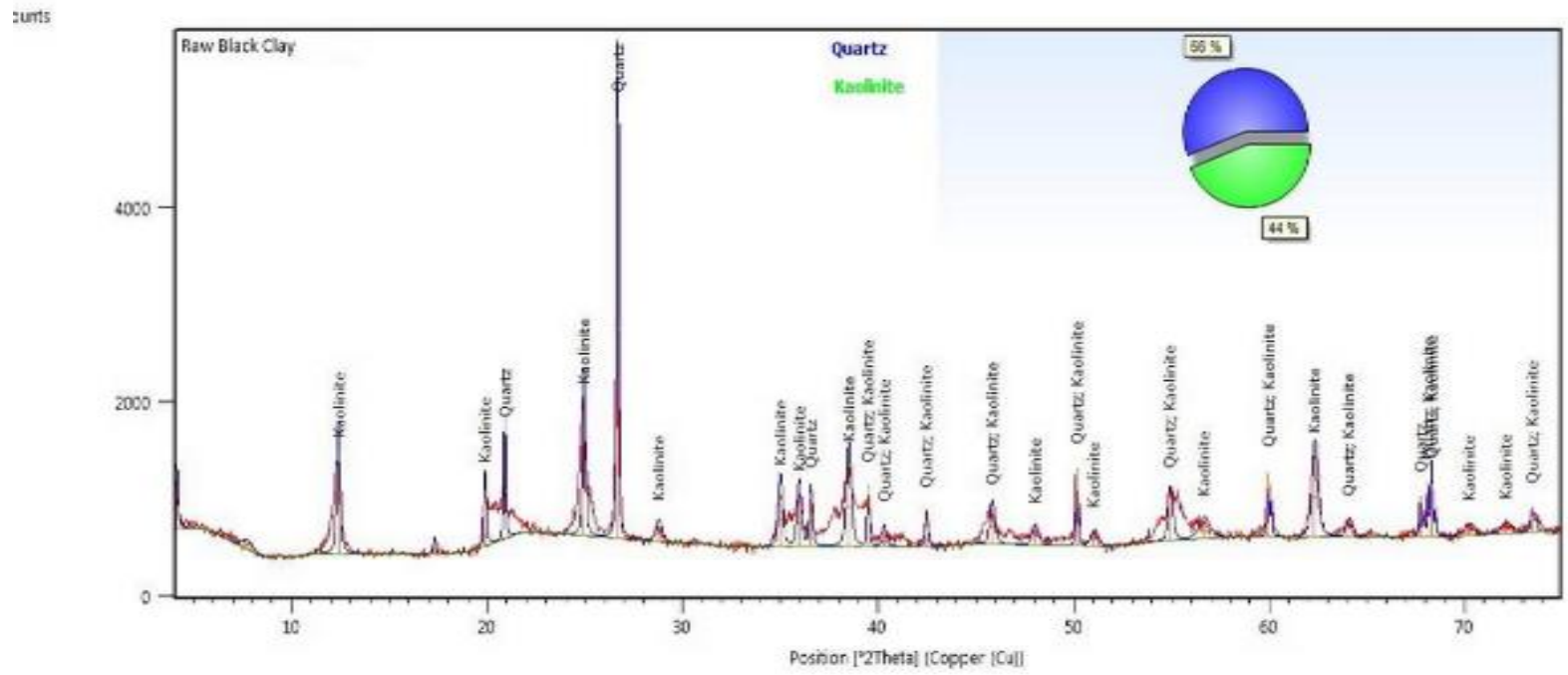

Figure 1: XRD of unmodified Iyi-Nsukka kaolinite clay catalyst (UMIKCCat)

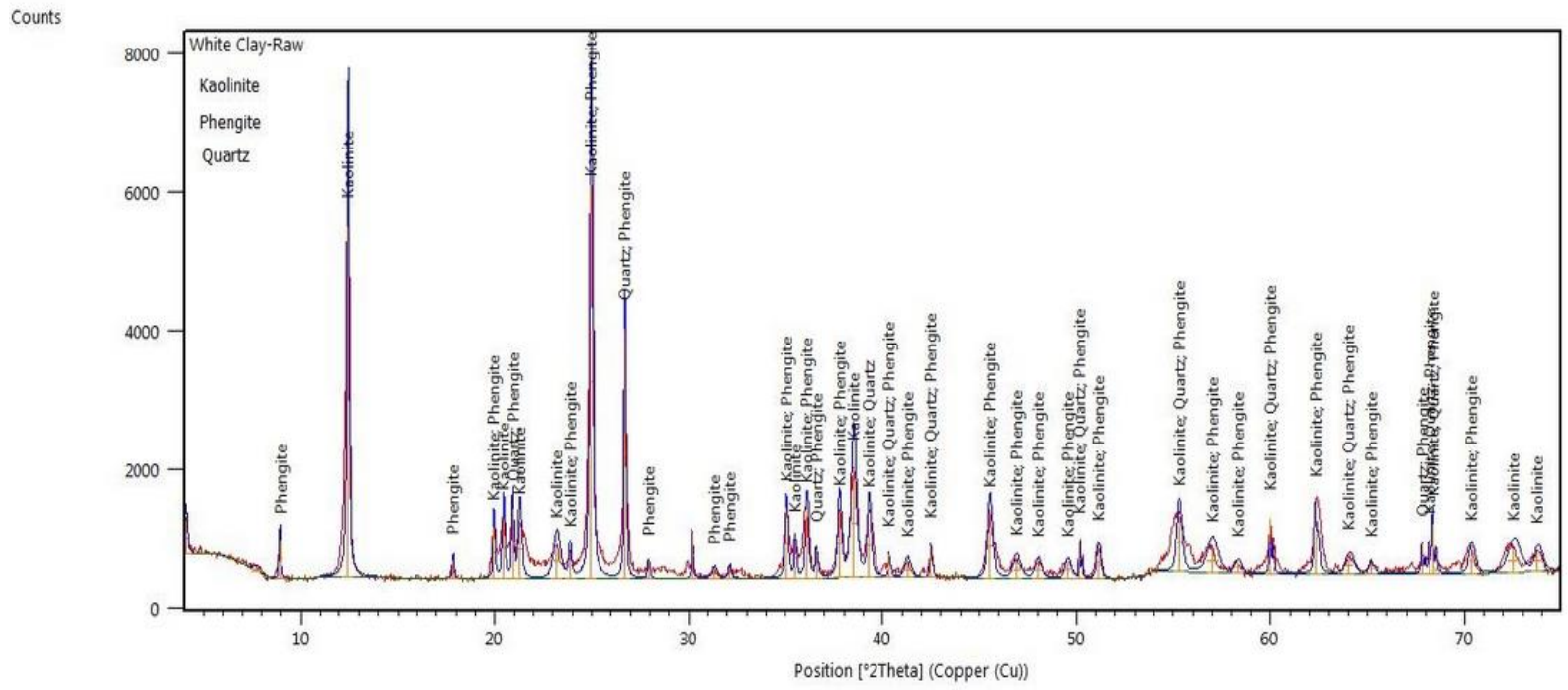

Figure 2: XRD of unmodified Ukpo kaolinite clay catalyst (UMUKCCat)

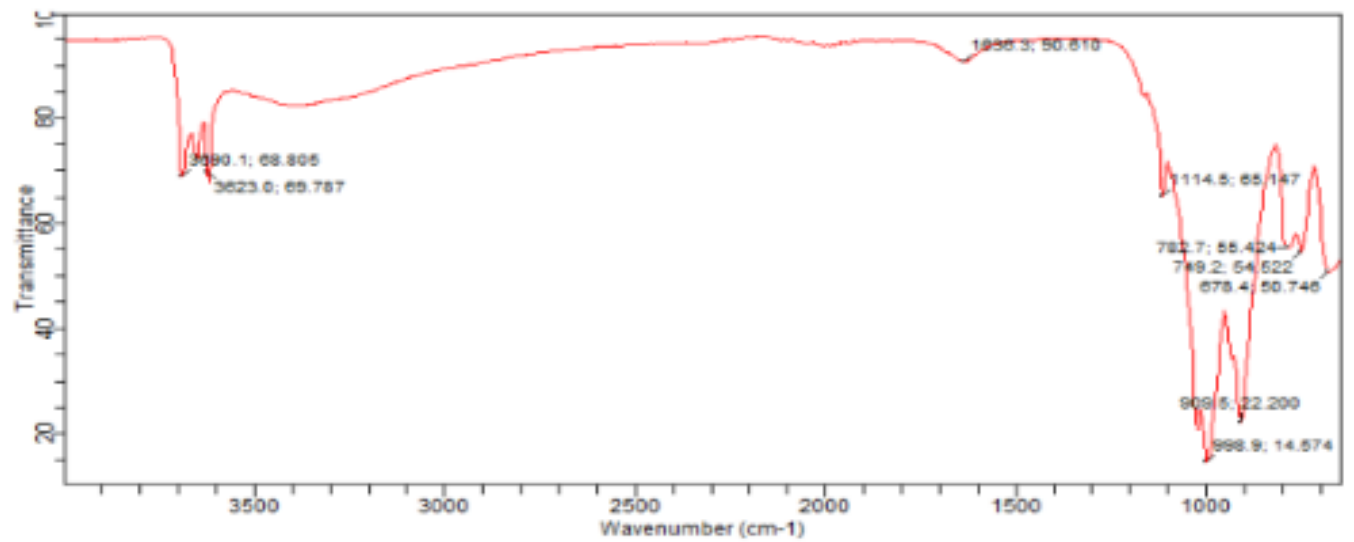

Figure 3: FTIR of unmodified Iyi-Nsukka kaolin clay catalyst 


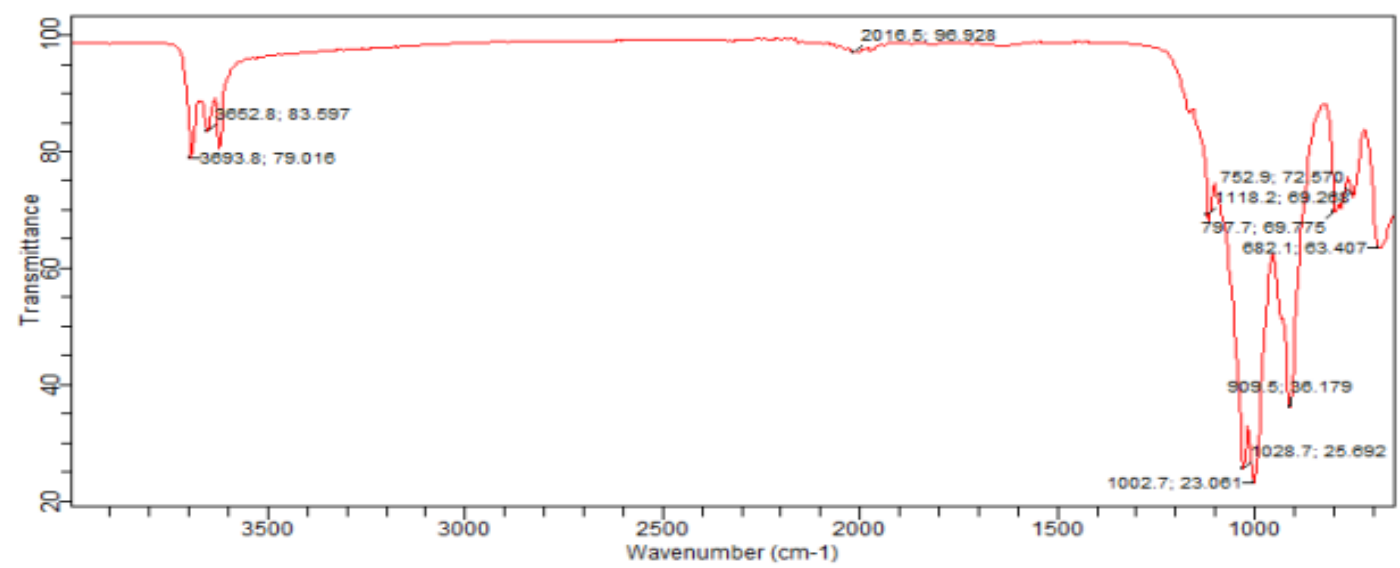

Figure 4: FTIR of unmodified Ukpo kaolin clay catalyst

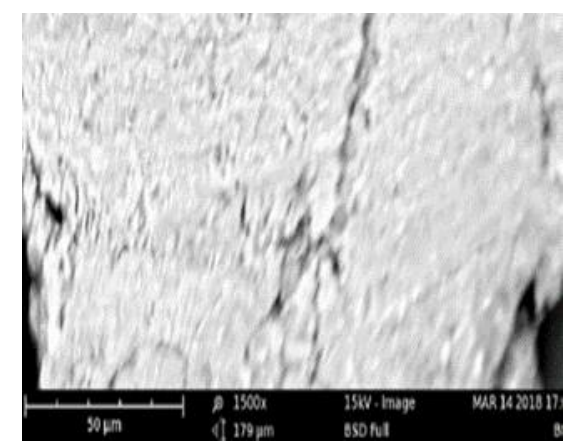

Plate 1: SEM of unmodified Iyi-Nsukka kaolin clay catalyst.

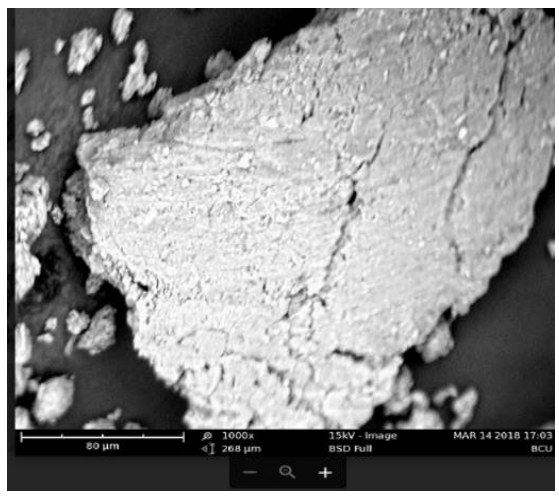

Plate 2: SEM of unmodified Ukpo kaolin clay catalyst 
Table 1: Elemental composition of (UMIKCCat) and (UMUKCCat)

\begin{tabular}{ccc}
\hline Composition & UMIKCCat & UMUKCCat \\
\hline $\mathrm{Al}_{2} \mathrm{O}_{3}$ & 44.00 & 42.30 \\
$\mathrm{SiO}_{2}$ & 56.00 & 51.69 \\
$\mathrm{Fe}_{2} \mathrm{O}_{3}$ & 0.00 & 4.20 \\
$\mathrm{ZnO}_{\mathrm{TiO}}$ & 0.00 & 0.00 \\
$\mathrm{TiO}_{2}$ & 0.00 & 0.50 \\
$\mathrm{~K}_{2} \mathrm{O}$ & 0.00 & 1.01 \\
$\mathrm{MgO}$ & 0.00 & 0.20 \\
$\mathrm{MnO}$ & 0.00 & 0.00 \\
$\mathrm{Na} 2 \mathrm{O}$ & 0.00 & 0.05 \\
\hline
\end{tabular}

Table 2: Physicochemical properties of (UMIKCCat) and (UMUKCCat)

\begin{tabular}{llll}
\hline Parameters & UMUKCCat & UMIKCCat & Range \\
\hline Moisture (\%) & 0.11 & 0.13 & $\geq 0.05$ \\
Bulk Density $\left(\mathrm{g} \mathrm{cm}^{-3}\right)$ & 1.27 & 0.81 & $0.8-1.3$ \\
$\mathrm{pH}$ & 3.81 & 2.27 & $2-4.6$ \\
Surface Area $\left(\mathrm{m}^{2} \mathrm{~g}^{-1}\right)$ & 778 & 721 & $670-800$ \\
Carbon (\%) & 3.49 & 4.11 & $1-6$ \\
Organic Matter $(\%)$ & 10.35 & 12.19 & $5-15$ \\
Loss On Ignition $(\%)$ & 17.80 & 29.40 & $13-30$ \\
Particle Density $(\mathrm{g} \mathrm{cm})^{-3)}$ & 2.11 & 51.75 & $51-58$ \\
Total porosity $(\%)$ & 52.36 & 2.60 & $2.1-2.6$ \\
& & & \\
\hline
\end{tabular}

\section{OIL [ SAMPLE-(02)]}

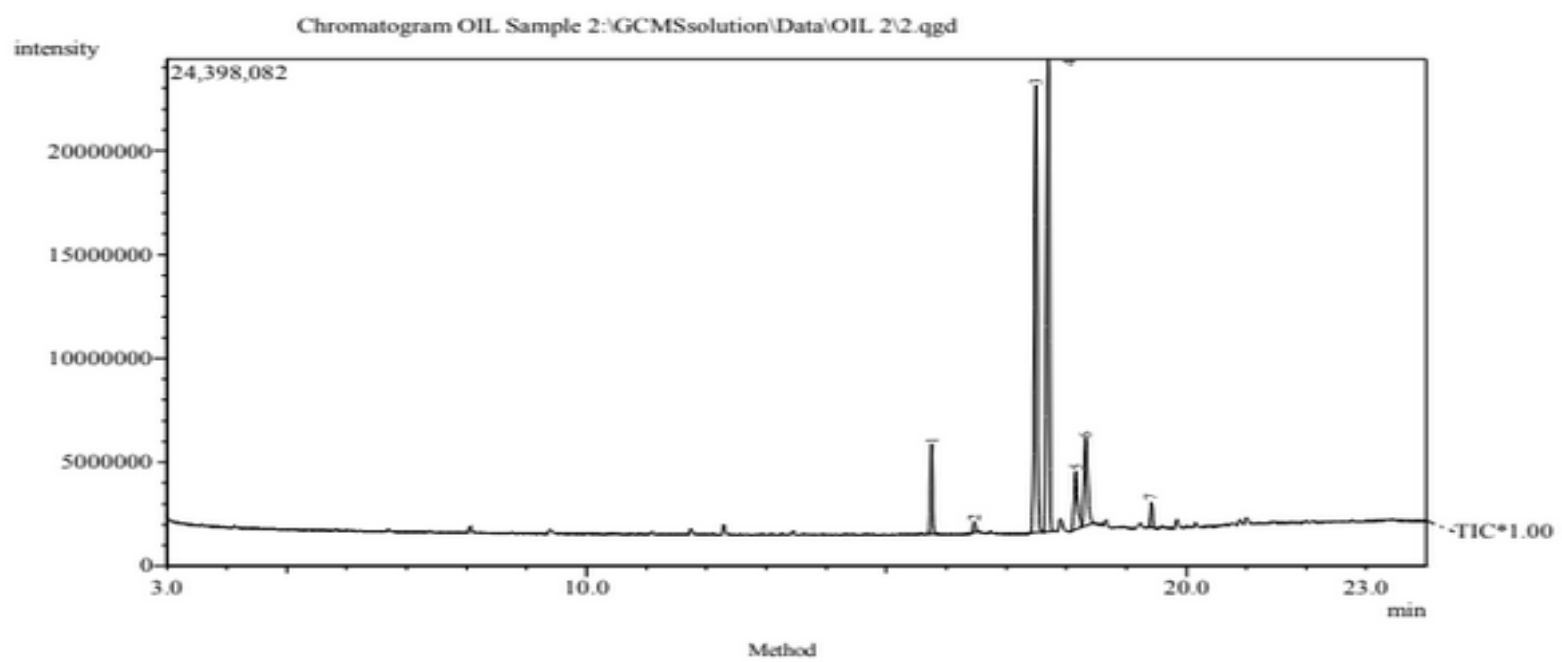

Figure 5: The fatty acid profile of gmelina seed oil 
Table 3: Physiochemical properties of gmelina seed oil

\begin{tabular}{|c|c|c|}
\hline Properties & $\begin{array}{l}\text { gmelina } \\
\text { seed oil }\end{array}$ & Range \\
\hline Specific gravity & 0.90 & $0.860-0.92$ \\
\hline Kinematics viscosity $\left(\mathrm{mm}^{2} / \mathrm{s}\right)$ at $40^{\circ} \mathrm{C}$ & 7.75 & $1.9-6.0(\mathrm{ASTM} / \mathrm{D} 445)$ \\
\hline Free fatty acid (mg K0H/Kg) & 1.53 & $\leq 3(\mathrm{ASTM})$ \\
\hline Iodine value $(\mathrm{g} / 100 \mathrm{~g})$ & 36.50 & $\leq 90(\mathrm{EN} 14111)$ \\
\hline Density $(\mathrm{g} / \mathrm{ml})$ & 1.48 & \\
\hline Saponification value $(\mathrm{mg} \mathrm{KOH} / \mathrm{Kg})$ & 161.49 & $196-205$ \\
\hline Refractive index & 1.4985 & $1.447-1.490$ \\
\hline Peroxide value $\mathrm{Meq} / \mathrm{Kg}$ & 0.91 & $0.1-5(\mathrm{ASTM})$ \\
\hline Moisture content $(\%)$ & 0.09 & $\leq 0.1($ ASTM $)$ \\
\hline
\end{tabular}

Effects of process parameters on the yield of biodiesel

The effect of catalysts concentrations expressed as weight percentage of the oil on the methyl ester yield was presented in Figure 6. The effect of catalysts concentrations were studied within the range of $1-6 \mathrm{wt} . \%$, The yield of methyl ester increased with increase in catalyst weight up to 3 wt.\% for both catalysts. Excess catalyst concentration beyond the optimum causes mixing problems and thereby inhibiting the formation of methyl ester resulting to slight decrease in biodiesel yield as shown at 5\% wt. catalyst concentration as presented in Figure 6 the trend is attributed to increase in viscosity of reactant mixture. The observation is in line with the findings of Faruque, (2020); Hossain, (2020), Yursoff, (2020).

The effect of reaction time were investigated within the range of 1-6 hours on the methyl ester yield. It was found that biodiesel yield increased with increase in reaction time up to 3 hours. Further increase in time up to 5 hours resulted to slight decreased yield of biodiesel as shown in Figure 7. The decrease in biodiesel yield is due to slight dissolution of glycerol in the reactants mixture as reaction prolongs which resulted to slight increase in viscosity of reactants mixture and thereby inhibit biodiesel yield. The observation is in line with the findings of Faruque, (2020); Hossain, (2020), Yursoff, (2020).

The effect of temperature on the yield of the methyl ester was studied, the reaction temperature was varied within the range of 30 to $80^{\circ} \mathrm{C}$. As shown in Figure 8, it was observed that biodiesel yield increased with increase in temperature up to $60^{\circ} \mathrm{C}$ and then decreased with the increased temperature. This is due to loss of methanol through vaporization since boiling point of methanol is $64.7^{\circ} \mathrm{C}$. The loss of methanol reduced the methanol/oil molar ratio resulted to increase in viscosity of the reactants mixture thereby retards the formation of methyl ester yield. The observation is in line with the findings of Faruque, (2020); Hossain, (2020), Yursoff, (2020).

The Effect of methanol/oil molar ratio on methyl ester yield were studied within the range of 6:1-14:1 methanol/oil molar ratio. It was observed that increase in methanol/oil molar ratio increase the biodiesel yield as shown in Figure 9. Methanol in sufficient ratio increases the solubility and homogeneity of the reactants mixture, enhance interaction of the reactants mixture which resulted to increase in biodiesel yield. The higher molar ratio shift the reaction in forward direction, reduces catalyst concentration in the reactants mixture, increase the cost of production and recovery of methanol.

The Effect of agitation speed on methyl ester yield were studied within the range of 100-600 $\mathrm{rpm}$, the methyl ester yield increased with increase in agitation speed up to 300rpm and started decreasing with increased in agitation speed up to $600 \mathrm{rpm}$ as shown in figure 10. The decreased yield is due to random dispersion of reactants mixture on the walls of the reactor causing interference on the reactants medium. The observation is in line with the findings of Faruque, (2020); Hossain, (2020), Yursoff, (2020). 


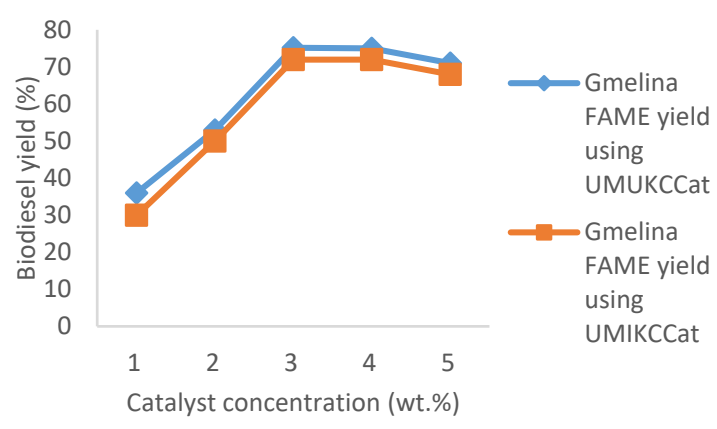

Figure 6: Effect of catalyst concentration on gmelina seed biodiesel yield

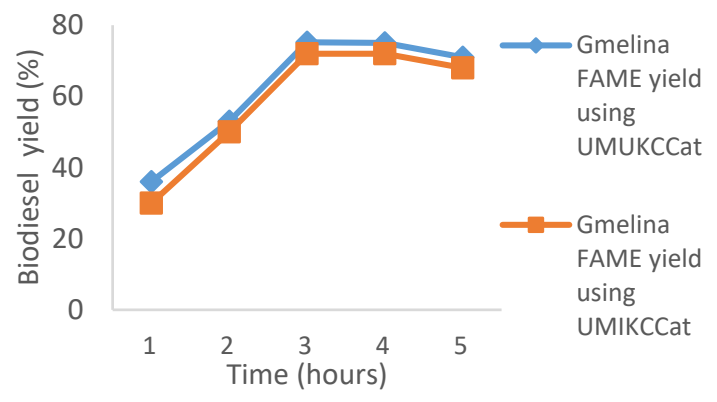

Figure 7: Effect of time on gmelina seed oil biodiesel yield.

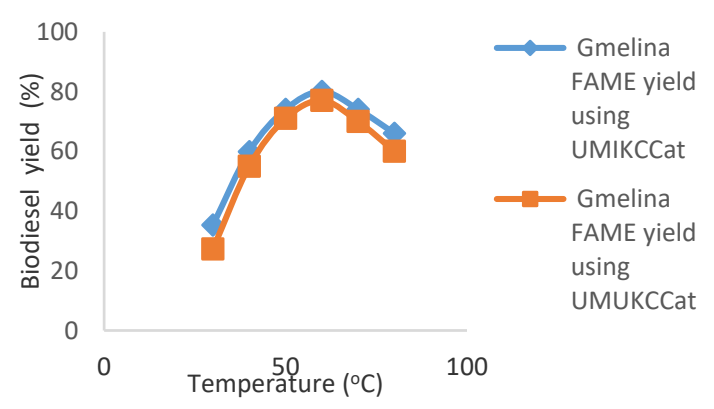

Figure 8: Effect of temperature on gmelina seed oil biodiesel yield

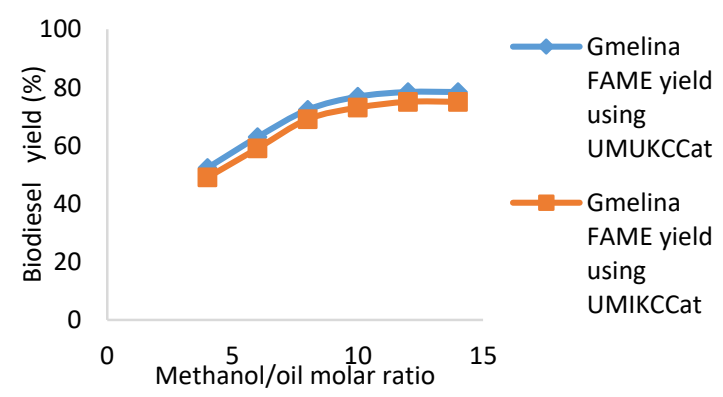

Figure 9: Effect of methanol/oil molar ratio on gmelina seed oil biodiesel yield.

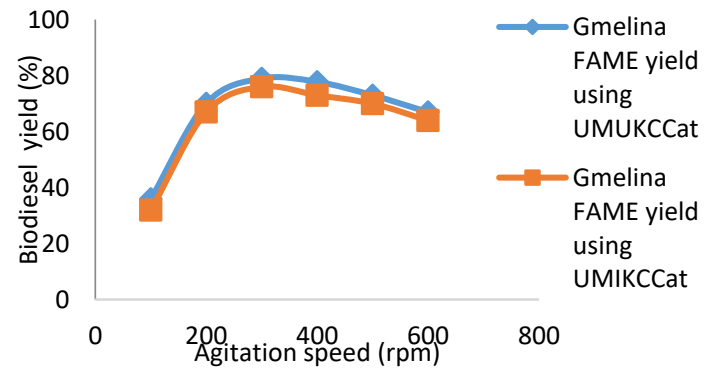

Figure 10: Effect of agitation on gmelina seed oil biodiesel yield

Statistical analysis presented quadraticregression equations that fitted the experimental values are given by Eq. (3) and Eq. (4), respectively for the yield of fatty acid methyl ester using unmodified Iyi-Nsukka kaolinitic clay catalyst (UMIKCCat) and unmodified Ukpo kaolinitic clay catalyst (UMUKCCat). Where $\mathrm{Y}$ is the response of the variables (percentage biodiesel yield) and A-E are the coded parameters of the independent variables studied namely: methanol-oil-molar ratio, catalyst concentration, temperature, reaction-time and agitation-speed, respectively. The equations represent the quantitative effect of the factors (A, B, C, D, and E) upon the response (Y). Eq. (3) and Eq. (4) suggested that the yield of biodiesel has linear and quadratic effects on five variables studied. Coefficients with one factor represent the single effect of that particular factor while the coefficients with more than one factor represent the interaction between those factors. Positive sign in front of the terms indicate synergistic effect while negative sign indicates antagonistic effect of the factors.

$\mathrm{Y}=+78.09+0.1450 \mathrm{~A}+0.4608 \mathrm{~B}-1.32 \mathrm{C}-1.68 \mathrm{D}$

$+0.7100 \mathrm{E}-0.1162 \mathrm{AB}+0.5875 \mathrm{AC} \quad-0.6025 \mathrm{AD}$ $+1.03 \mathrm{AE}-0.7800 \mathrm{BC}+0.8900 \mathrm{BD}-0.8275 \mathrm{BE}-$

$0.3162 \mathrm{CD}-1.65 \mathrm{CE}+1.44 \mathrm{DE} 0.5702 \mathrm{~A}^{2}+0.7210 \mathrm{~B}^{2}$ $+0.9423 \mathrm{C}^{2}+0.4773 \mathrm{D}^{2}-0.2590 \mathrm{E}^{2}$

$\mathrm{Y}=+78.46-0.042 \mathrm{~A}+0.5242 \mathrm{~B}-1.32 \mathrm{C}-1.58 \mathrm{D}$ $+0.4717 \mathrm{E}-0.0650 \mathrm{AB} \quad+0.1987 \mathrm{AC}-0.5763 \mathrm{AD}$ $+0.8813 \mathrm{AE}-1.06 \mathrm{BC}+0.4762 \mathrm{BD}-0.3387 \mathrm{BE}-$ $0.5550 \mathrm{CD}-1.69 \mathrm{CE}+1.97 \mathrm{DE}-0.4330 \mathrm{~A}^{2}+0.8695 \mathrm{~B}^{2}$ $+1.12 \mathrm{C}^{2}+0.5658 \mathrm{D}^{2}-0.1255 \mathrm{E}^{2}$

Design Expert sequential model sum of squares and the model test statistics as shown in Table 4 and Table 5 respectively were used to test the adequacy of the proposed models for the yield of biodiesel using (UMIKCCat) and (UMUKCCat) catalysts. From the statistical analysis, the regression coefficient $\left(R^{2}=0.9989\right)$, the Predicted $R^{2}$ of 0.9710 is in reasonable agreement with the Adjusted $\mathrm{R}^{2}$ of 0.9969 ; i.e. the difference is less than 0.2 for (UMIKCCat) catalyst also the regression coefficient $\left(\mathrm{R}^{2}=0.9975\right.$, the Predicted $\mathrm{R}^{2}$ of 0.9376 is in reasonable agreement with the Adjusted $\mathrm{R}^{2}$ of 
0.9931 ; i.e. the difference is less than 0.2 . for (UMUKCCat) catalyst.

Table 4 : Significance of regression coefficients of the yield of biodiesel produced fro gmelina seed oil using unmodified Iyi-Nsukka kaolin clay catalyst (UMIKCCat)

\begin{tabular}{lllllr}
\hline Source & $\begin{array}{l}\text { Sum } \\
\text { Squares }\end{array}$ & $\begin{array}{l}\text { of } \\
\text { Segree of } \\
\text { freedom }\end{array}$ & $\begin{array}{l}\text { Mean } \\
\text { Square }\end{array}$ & F-value & p-value \\
\hline A-Molar ratio & 328.31 & 20 & 16.42 & 522.34 & $<0.0001$ Significant \\
B-Catalyst & 0.5046 & 1 & 0.5046 & 16.06 & 0.0021 \\
concentration & 5.10 & 1 & 5.10 & 162.18 & $<0.0001$ \\
C-Temperature & 41.66 & 1 & & & \\
D-Reaction time & 67.40 & 1 & 41.66 & 1325.59 & $<0.0001$ \\
E-Agitation speed & 12.10 & 1 & 67.40 & 2144.71 & $<0.0001$ \\
AB & 0.2162 & 1 & 12.10 & 384.97 & $<0.0001$ \\
AC & 5.52 & 1 & 0.2162 & 6.88 & 0.0237 \\
AD & 5.81 & 1 & 5.52 & 175.72 & 0.0012 \\
AE & 16.97 & 1 & 5.81 & 184.81 & 0.0011 \\
BC & 9.73 & 1 & 16.97 & 540.12 & $<0.0001$ \\
BD & 12.67 & 1 & 9.73 & 309.75 & $<0.0001$ \\
BE & 10.96 & 1 & 12.67 & 403.27 & $<0.0001$ \\
CD & 1.60 & 1 & 10.96 & 348.62 & $<0.0001$ \\
CE & 43.49 & 1 & 1.60 & 50.92 & 0.0002 \\
DE & 33.12 & 1 & 43.49 & 1383.96 & $<0.0001$ \\
$A^{2}$ & 9.54 & 1 & 33.12 & 1053.87 & $<0.0001$ \\
$B^{2}$ & 15.25 & 1 & 9.54 & 303.50 & $<0.0001$ \\
$C^{2}$ & 26.04 & 1 & 15.25 & 485.24 & $<0.0001$ \\
$D^{2}$ & 6.68 & 1 & 26.04 & 828.72 & $<0.0001$ \\
$E^{2}$ & 1.97 & 1 & 6.68 & 212.61 & $<0.0001$ \\
\hline
\end{tabular}

Table 5 : Significance of regression coefficients of the yield of biodiesel produced from gmelina seed oil using (UMUKCCat) catalyst

\begin{tabular}{lllllr}
\hline Source & $\begin{array}{l}\text { Sum } \\
\text { Squares }\end{array}$ & $\begin{array}{l}\text { of } \\
\text { freedom }\end{array}$ & $\begin{array}{l}\text { of } \\
\text { Square }\end{array}$ & F-value & p-value \\
\hline Model & 341.43 & 20 & 17.07 & 5458.57 & $<0.0001$ significant \\
A-Molar ratio & 0.04 & 1 & 0.04 & 13.32 & 0.0072 \\
B-Catalyst & 6.59 & 1 & 6.59 & 2108.41 & $<0.0001$ \\
concentration & & & & & \\
C-Temperature & 41.82 & 1 & 41.82 & 13371.02 & $<0.0001$ \\
D-Reaction time & 60.10 & 1 & 60.10 & 19217.82 & $<0.0001$ \\
E-Agitation speed & 5.34 & 1 & 5.34 & 1707.21 & $<0.0001$ \\
AB & 0.0676 & 1 & 0.0676 & 21.61 & 0.0007 \\
AC & 0.6320 & 1 & 0.6320 & 202.09 & 0.0002 \\
AD & 5.31 & 1 & 5.31 & 1698.82 & $<0.0001$ \\
AE & 12.43 & 1 & 12.43 & 3973.05 & $<0.0001$ \\
BC & 17.85 & 1 & 17.85 & 5707.67 & $<0.0001$ \\
BD & 3.63 & 1 & 3.63 & 1160.37 & $<0.0001$ \\
BE & 1.84 & 1 & 1.84 & 587.06 & $<0.0001$ \\
CD & 4.93 & 1 & 4.93 & 1575.84 & $<0.0001$ \\
CE & 45.56 & 1 & 45.56 & 14568.44 & $<0.0001$ \\
DE & 62.09 & 1 & 62.09 & 19854.46 & $<0.0001$ \\
$A^{2}$ & 5.50 & 1 & 5.50 & 1758.13 & $<0.0001$ \\
$B^{2}$ & 22.18 & 1 & 22.18 & 7091.72 & $<0.0001$ \\
$C^{2}$ & 36.93 & 1 & 36.93 & 11808.31 & $<0.0001$ \\
$D^{2}$ & 9.39 & 1 & 9.39 & 3002.52 & $<0.0001$ \\
$E^{2}$ & 0.4617 & 1 & 0.4617 & 14.62 & 0.0023 \\
\hline
\end{tabular}


Analysis of variance (ANOVA) for biodiesel yield using (UMIKCCat) and (UMUKCCat) catalysts

The ANOVA results for the model terms are given in Table 4. ANOVA was applied to estimate the significance of the model at 5\% significance level. A model is considered significant if the p-value (significance probability value) is less than 0.05 . From the $p$-values presented in Tables 4 , it can be stated that all the linear terms $A$, B, $\mathrm{C}, \mathrm{D}$ and $\mathrm{E}$ interaction terms $\mathrm{AB}, \mathrm{AC}, \mathrm{AD}, \mathrm{AE}, \mathrm{BC}, \mathrm{BD}, \mathrm{BE}, \mathrm{CD}, \mathrm{CE}, \mathrm{DE}$ and quadratic terms $\mathrm{A}^{2}, \mathrm{~B}^{2}, \mathrm{C}^{2}$, and $\mathrm{D}^{2}$ were significant model terms wheras in table 5, it can be stated that all the linear terms $\mathrm{A}, \mathrm{B}, \mathrm{C}, \mathrm{D}$ and $\mathrm{E}$, and interaction terms $\mathrm{AB}, \mathrm{AC}, \mathrm{AD}, \mathrm{AE}, \mathrm{BC}, \mathrm{BD}, \mathrm{BE}, \mathrm{CD}, \mathrm{CE}, \mathrm{DE}$ and quadratic terms $\mathrm{A}^{2}, \mathrm{~B}^{2}, \mathrm{D}^{2}$ and $\mathrm{E}^{2}$ were significant model terms.

\section{Conclusion}

The Performance evaluation of unmodified Iyi-Nsukka kaolinite clay and unmodified Ukpo Kaolinite clays as catalysts for transesterification of gmelina seed oil were investigated as an effort geared towards development of economical pathway for biodiesel production through the utilization of abundantly available, cheap, noncorrosive, non-toxic, easy- separable, recyclable, reusable and environmentally friendly catalysts. IyiNsukka and Ukpo kaolin clay were prepared. Gmalina seed oil were extracted using soxhlet extraction method, the catalysts and oil were physically and chemically characterised. The percentage oil extracted from the gmelina seed proved that they it is viable feedstock for biodiesel

\section{Reference}

1. Adam, J.D. (1975) Un Grad Projet de Plantation de gmelina au Liberia, Agric.botany applied journal, 22: 59-66

2. Belver, C., Munoz, M.A., Vicente., M.A.(2002) Chemical activation of kaolin under acid and alkaline conditions Chem. Mater. Journal. 14: $2033-1$

3. Burkill, H. M. (2000) The useful plant of West tropical Africa. Royal botanic gardens Kew, London, UK, Families S-Z. Cryptograms Addenda 5: 257-258.

4. Demirbas, A. (2003). Comparison of transesterification methods for production of biodiesel from vegetable oils and fats. Energy conversion and journal, 49, 125- 130. production. The methyl ester produced by transesterification of gmelina seed oil were within acceptable ASTM limits and process parameters such as reaction time, catalyst concentration, methanol/oil ratio, reaction temperature and agitation speed affected biodiesel yield. Central Composite Design (CCD) of Response Surface Methodology (RSM) was adequate in predicting and optimizing the biodiesel production. It were observed the structural surface area and porosity of the clay catalysts affect the yield of biodiesel. The performance of both catalyst were appreciable showing that upon modification, the catalysts activity will improve enormously as a result of expected increase in surface area and porosity, the study prove that both catalysts has potentials to enhance biodiesel production.
5. Demirbas, A. (2009). Progress and recent trends in biodiesel fuels. Energy conversion and management journal, 50,14-34.

6. Diko, M., Ekosse, G., \& Ogala, J. (2016). Fourier transform infrared spectroscopy and thermal analysis of kaolinitic clay from South Africa and Cameroon. Acta geodynamica et geromaterialia, 13, 2, 149.

7. Faruque, M. O., Razzak, S.A. \& Hossain, M.M. (2020).Application of heterogeneous catalysts for biodiesel production from microalgal oil- A review. Catalysis journal, 10 (9) 1025.

8. Horvath, E., Kristof, J., Mako, E., (2003) Thermal treatment of machanochemically activated kaolinite. Thermochim. Acta 404:20 
9. Horvath, E., Kristof, J., Jakab, E. Mako, E., Vagvolgyi, V. (2005) Identification of super centres in formamide- intercalated kaolinite. Colloid interface science journal. 289: 132-138.

10. Hussain, F., Soudagar, M., Afzal, A. \& Mujtaba, M. (2020).

Enhancement in combustion, performance and emission characteristics of diesel engine fuelled with $\mathrm{Ce}-\mathrm{ZnO}$ nanao particle additive added to soya beans biodiesel blends. Energies journal, 13 (17), 4578.

11. Ledoux, R. White, J. (1966) Infrared studies of hydrogen donding interactions between kaolin surface intercalated potassium acetate, hydrazine, formamide and urea. Colloid interface science journal. 21(2) 127-238.

12. Lenarda, M., Storearo, L., Moretti, E., Riello, P., (2007). Solid acid catalyst from clays: Preperation of meso porous by chemical activation of metakaolinite under acid conditions Colloid interface science journal. 311: 537 -543.

13. Madejova, J., (2003) FTIR technique in clay mineral studies. Vib. Spectrosc. 31:1-4

14. Okada, K. (1988). Preperation of mesoporous silica from metakaolinite by selective leaching method. Microporous Mesoporous Mater 21:289-296.

15. Oueda, N., Bonz-Coulibaly, Y. L. \& Ouedraogo, I. W. K. (2017) Deactivation process, regeneration conditions and reusability performance of $\mathrm{CaO}$ or $\mathrm{MgO}$ based catalysts used for biodiesel production - A review. Materials sciences and applications journal, 8, 94-122.

16. Panda, B., Achyut, K., Mishraa, D.K., Mishrac, D. \& Singha, R. (2010). Colloids and surfaces A: Physicochemical engineering aspects. Applied clay science journal, 363, 98-10

17. Park, Y.M., Lee, D. W., Kim, D. K., Lee, J. S. \& Lee, K. Y. (2008). The heterogeneous catalyst system for the continuous conversion of free fatty acids in used vegetable oils for the production of biodiesel. Catalysis today, 131: 238-243.

18. Rhodes, C.N., Franks, M., Parkes, G. (1991). The effect of acid treatment on clay supported $\mathrm{Zncl}_{2}$ alkylation catalysts Chem. Society Journal 12: 804-807.

19. Rodrigues, M. (2003). Physcical and catalytic characterisation of smectites fro Boa-Vista, Paraiba, Bracil, Ceramica 49: 149-150.

20. Singh, S. P. \& Singh, D. (2010). Biodiesel production through the use of different sources and characterization of oils and their esters as the substitute of :A review. Renewable and sustainable energy journal, 14, 200-216

21. Srivastava, A. \& Prasad, R. (2000). Triglycerides-based diesel fuels. Renewable sustainable energy journal, 4, 111-133.

22. Stavarache, C., Vinatoru, M. (2005). Fatty acid methyl ester from vegitable oil by means of ultrasonic energy.Ultrason. Sonochem. 12: 367-372.

23. Talebian-Kiakalaieh, A., Amin, N. \& Mazaheri, H. (2013). A review on novel processes of biodiesel production from waste cooking oil. Applied energy journal, 104: 683-710.

24. Temujin, J., Burmaa, G., Amgalan,J. ( 2001) Preperation of porous silica for mechanical activation of kaolin . Porous Mater. 8:233238

25. Temujin, J.,(2001).Characterisation of porous silica prepared from mechanically amorphised kaolin selective leaching, Powder technology $121: 259-262$

26. Vagvalgyi, V. Kristof, J., E. Mako, E. (2008). Investigation of mechanochemically modified kaolin surface by thermo analytical spectroscopicmethods. Collid interface 317:523-529.

27. Varga, G., (2007). The structure of kaolin and metakaolin. Epitoanyag 59: 4-8. 
28. Wada. K., (1962) Lattice expansion of kaolinite minerals bybtreatment with potassium acetate. Miner. 46:78-91.

29. Xu, L., Yang, X., Yu, X., Guo, Y. \& Maynurkader, E. (2010).

Preparation of mesoporous polyoxometalate-tantalum pentoxide composite catalyst for efficient esterification of fatty acid. Catalysis community journal, 9, 1607-1611.

30. Yusoff, M. H., Ayoub, M., Juisoh, N. \& Abdullah, A. Z. (2020). The challenges of biodiesel implementation program in Malaysia. Processes journal, 8 (10), 1244

31. Zhou, C. H., (2010) Emmerging trends challenges in synthetic clayb base minerals and layered double hydroxides. Applied clay sci. 48:1-4. 